\title{
Kam kráčíš, Evropo?
}

\section{Vážení čtenáři,}

se začátkem roku jsou obvykle spojené dlouhé zimní večery, kdy sentimentálně vzpomínáme na sluncem prohřátou dovolenou prožitou u jihoevropských moří. První měsíce letošního roku si však naši pozornost vysloužilo Řecko z trochu jiného důvodu, než který představuje krása řeckých letovisek.

Př́ijemný pocit z toho, jak snadné může být žití na dluh, se v řeckém kraji začal postupně proměňovat $\mathrm{v}$ černou můru strachu $\mathrm{z}$ budoucnosti. Nutno přiznat, že překračování veřejných výdajů oproti veřejným př́ijmům má již v této zemi svoji několikaletou tradici. V roce 2009 rozdíl mezi oběma veličinami dosáhl svého vrcholu, když 125 mld. EUR veřejných výdajů hravě převýšilo 89 mld. EUR veřejných př́ijmů. Aby se ovšem snad čtenářum neudělalo z podobných dat špatně, řečtí statistici ${ }^{1}$ pro jejich pohodlí vždy čísla „korektně“ upravili. Podobný postup slavil úspěch a země, která se dívala na konvergenční kritéria, jejichž splnění bylo nezbytně nutné pro přijetí eura, vždy z uctivé vzdálenosti, dokázala statistický „zázrak“a v roce 2001 byla přijata do Evropské měnové unie. Žádné tajemství se údajně dlouho neutají, to řecké však vydrželo několik let.

$\mathrm{K}$ dobru řeckých politiků je třeba připsat, že pomocí veřejných výdajů se snažili i vylepšit blahobytný život svých voličů. Státní zaměstnanci dostávali své třinácté i čtrnácté měsíční platy, včetně všech možných bonusů třeba i za dodržování pracovní doby. Do důchodu bylo možné odejít už v 53 letech. Na ostrově Agios Efstratios údajně existovala škola se 40 placenými učiteli a jen 10 žáky. ${ }^{2}$

Závist však není na místě. Probuzení z bezstarostné kocoviny muselo být určitě značně nepř́jemné. Finanční pomoc ze strany Mezinárodního měnového fondu a Evropské unie, jak se zdá, však nepomohla. Podíl veřejného dluhu na hrubém domácím produktu se v Řecku dokonce zvýšil ze 126 \% v roce 2009 na $177 \%$ v roce 2014 . Proto se dnes více než drríve hovoří o smyslu další pomoci Řecku a o jeho dalším setrvání v Evropské měnové unii. Obava, že by nevyřešení řecké dluhové krize mohlo ohrozit samotnou existenci Evropské unii, není na místě. Tedy aspoň tak můžeme doufat.

1 Data pro tuto předmluvu nejsou převzata ze statistického úřadu Řecka, ale ze Statista: Greece. [on-line], Hamburg, Statista, c2015, [cit. 31. 3. 2015],

$<$ http://www.statista.com/topics/2475/greece//>.

2 Viz např. Ahrens, F.: Greek Debt: Bailout Concessions not Early Spartan Enough. [on-line], Washington Post, 3. 5. 2010, [cit. 13. 1. 2015],

$<\mathrm{http} / /$ voices.washingtonpost.com/economy-watch/2010/05/greek_debt_bailout_co ncessions.html>. 
Připomeňme si, že v antické mytologii se objevuje př́iběh o dívce, která se pyšní jménem našeho kontinentu. Jedná se o krásnou princeznu Európa, dceru týrského ${ }^{3}$ krále Agénora. Do jejího života osudově zasáhl sám nejvyšší řecký bůh Zeus. Zaujat její krásou, přeměnil se v mladého hezkého býčka a poté co nerozvážná Európa usedla na jeho hřbet, vydal se s ní i přes její odpor na širé moře. Marně ji její rodina hledala, lstivost Diova zvítězila.

Tvrdit ovšem, že olympští bohové byli všichni lstiví a ve slibech nespolehliví, není pravda. Lze mezi nimi nalézt i takové osobnosti, které se rozhodly dodržet svůj slib i přesto, že věděly, jaké nebezpečí ze splnění tohoto slibu bude plynout jak pro ně samotné, tak i pro celé lidstvo. Sluneční bůh Helios ve slabé chvilce slíbil svému synovi Faethóntovi, že mu splní jakékoliv jeho přání. Synka bohužel nenapadlo nic jiného než požádat svého otce, aby mu půjčil aspoň na chvíli svůj sluneční vůz, s nímž pravidelně vykonává cestu po nebeské obloze. Svou jízdu však Faethón nezvládl, sluneční oři se splašili a žár slunečního vozu spálil úrodnou půdu velké části země na ploše dnešní Arábie a Sahary, takže nyní se tam nachází jen samý písek. Pouze včasný zásah Diův, který srazil onoho šíleného řidiče z vozu, zabránil nejhoršímu a zachránil tak celou Zemi. Nikdy jsem proto nepochopil, proč automobilka Volkswagen pojmenovala svi̊j luxusní vůz Phaethon po osobě, která podle antické mytologie zapříćinila v podstatě největší ekologickou katastrofu všech dob. Na Faethóntově náhrobku se lze podle Ovidia dočíst, že sice ,padl, ale při velkém a odvážném činu“.4

Za velký a odvážný čin lze zajisté považovat i založení Evropské unie. Krásné ideály o svobodě, demokracii a lidských právech by se v ní podle představ zakladatelů měly spojovat s hospodářskými a bezpečnostními zájmy jednotlivých členských zemí. Řízení něčeho tak složitého jako je Evropská unie však vyžaduje zkušené a obratné vozky, kteři myslí více na obyvatele členských zemí než sami na sebe a na své znovuzvolení. V opačném př́padě lze očekávat, že „koně“ pod jejich vedením se splaší, stanou se neřiditelnými a dojde k pádu celého unijního vozu.

prof. Ing. Petr Marek, CSc.

předseda redakční rady

Českého finančního a účetního časopisu

3 Týrské království představuje jedno z hlavních království starověké Fénicie, město Týros lze na mapě nalézt na jihu Libanonu na pobřeží Středozemního moře.

4 Latinsky: „Quem Si Non Tenuit, Magnis Tamen Excidit Ausis“ viz Publius Ovidius Naso: Metamorphosen. Libro Secundo. [online], San Francisco, Wikimedia, c2012, [cit. 10.3.2015], <https://la.wikisource.org/wiki/Metamorphoses_(Ovidius)/Liber_II>. 